\title{
El milenarismo y su relación con la politica: una perspectiva desde la Antropología Politica
}

\section{Maria Victoria Fernández}

Desde sus inicios, la Antropología Política se ha interesado en la investigación del milenarismo como una forma de movimiento social que, teniendo su origen en creencias religiosas, evoluciona en muchos casos, por no decir en la mayoría, como movimiento secular, pretendiendo efectuar cambios que influyan en el sistema político. Esta metamorfosis se lleva a cabo tanto en culturas llamadas "primitivas" como dentro del contexto de los pueblos "civilizados". Debido a su misma esencia, el milenarismo no es fácil de reconocer como variable independiente dentro de los movimientos sociales, ya que son inherentes a él su espontaneidad e indeterminación.

Ante la proximidad del tercer milenio, creemos de interés hacer un breve análisis del milenarismo desde una perspectiva sociopolítica. Hay quienes piensan que transformaciones profundas sobrevendrán durante los años 2000, lo que produce aprensiones en algunos, así como en otros optimismo, esperanzados por la perspectiva cercana de un mundo mejor.

Los medios de comunicación nos informan de personalidades a nivel mundial, regional y comunitario instando al pueblo a una preparación eficaz para enfrentar cambios inminentes y necesarios. Hay presagios de un nuevo oscurantismo amenazante, así como de progreso inimaginable, presionando a grupos sociales hacia un supuesto límite de su historia. El futuro pareciera gravitar sobre la humanidad más que el presente. El siglo XXI es invocado por líderes que apoyan su llamado en la urgencia de concretar proyectos y acciones audaces e innovadores; portadoras de la promesa de una utópica perfección terrenal semejante al mitico pasado feliz. Las antiguas creencias milenaristas aparecen recurrentes, subyaciendo en el tiempo, surgiendo bajo variadas formas según la cultura y circunstancias históricas, cristalizándose como movimientos prepolíticos en las sociedades segmentarias 
sin Estado y como políticos cuando aparecen en sociedades con instituciones políticas desarrolladas y consolidadas.

\section{ORIGEN Y DOCTRINA DEL MILENARISMO}

La tradición milenarista occidental se desarrolló en el zoroastrismo persa $^{1}$ y sobre todo en el judaísmo, desde donde pasó al cristianismo. El milenarismo tiene sus raíces en las visiones y esperanzas mesiánicas del judaísmo profético, que se nutren de la Revelación y de la literatura apocalíptica. Dice San Juan en el Apocalipsis XX, 1-3: "vi bajar del cielo un ángel que tenía la llave del abismo y una gran cadena en la mano y tomó al dragón. la antigua serpiente que es el diablo Satán, y lo encadenó por mil años. Y habiéndole lanzado al abismo lo cerró sobre él y lo selló a fin de que no subyugase las naciones hasta que esos mil años se hubiesen cumplido después de lo cual deberá ser soltado por breve tiempo". Según la interpretación común de la tradición judeocristiana, la expresión "mil años" designa una época de paz relativa que debe preceder a las tribulaciones de los últimos días, a pesar de lo cual "durante los primeros siglos del cristianismo, muchos escritores eclesiásticos enseñaban que el vencedor de los césares perseguidores, el Cristo, debía aparecer próximamente para reinar sobre la tierra con sus santos durante diez siglos". Se los llamó "milenarios" y su doctrina recibió el nombre de "milenarismo" (Nouveau Larousse Ilustré, p. 98, T. IV).

El milenarismo postula, entonces, la reaparición de Cristo como guerrero que vencerá a Satanás, el Anticristo, y reinará en persona. constituyendo el Reino de Dios en la tierra. Al final de este periodo. el demonio será liberado antes de ser aniquilado definitivamente, y la victoria irá seguida de la resurrección de los muertos, el juicio final y la redención eterna.

La mayoría de los movimientos milenaristas son mesiánicos, ya que la salvación es obra de un redentor, un mediador entre lo divino y lo humano, siendo el líder de tendencia carismática.

\section{Algunos ejemplos de milenarismo}

El milenarismo ha desempeñado un papel importante en movimientos sociales en la Europa premoderna y moderna, así como en América, Oceanía y Africa.

-En la Europa Medieval, entre los siglos XI y XV, florecen diversos movimientos milenaristas diferentes entre sí. Un ejemplo lo constituyen los "espirituales franciscanos", ascetas procedentes de familias nobles unidas en alianzas matrimoniales a mercaderes que constituían

\footnotetext{
${ }^{1}$ Zoroastro: Fundadol o reformador de la religión persa o mazde ísmo.
} 
la clase dominante en las ciudades de una Italia no unificada. Su ideal de milenarismo era el de la renuncia total a la riqueza, convirtiéndose en pobres voluntarios, más pobres que los mendigos, recorriendo Europa predicando y anunciando la llegada de la perfección, unidos por la oración y la contemplación mística al resto de la humanidad en la era del Espíritu Santo.

En el otro extremo aparecía el milenarismo desarrollado entre los desposeídos de los campos y ciudades, cuya pobreza, "nada voluntaria" (СоHN, p. 46), los mantenía en extrema inseguridad y cuyo milenarismo fue espurio, violento, anárquico y, en oportunidades, revolucionario. Los pobres recibían su fe de presuntos profetas, oráculos y mesías que en muchos casos habían pertenecido a la baja clerecía y que a su vez habian tomado sus ideas de las tradiciones milenaristas judeocristianas de la fraternidad del Espíritu Libre, formada por misticos heréticos. Algunos de estos movimientos más importantes surgen durante las Cruzadas, inspirados en Joaquín de Fiore (siglo XII), el de los cátaros en el sur de Francia, llamados también albigenses, y valdenses. En Alemania tenemos el ejempio del Mito de Federico, los adamitas que se unieron a la guerra de los campesinos alemanes contra su señor e intentaron establecer el "Reino de Dios sobre la Tierra" y los importantes anabaptistas de la Reforma como Thomas Müntzer en Alemania. En Inglaterra hay que recordar durante la época de Cromwell a los quintomonarquistas que establecen el Parlamento de los Santos.

Los movimientos milenaristas que prometían la pronta reivindicación de los pobres, además de hacerse independientes, "fueron volviéndose más hostiles hacia los ricos y privilegiados" (COHN, p. 97). Las Cruzadas de los Pobres, compuestas por grupos de individuos sujetos a estrictas reglas ascéticas como no beber, jugar ni blasfemar, cuando finalizaron su objetivo, que era el de acabar con maleantes, se transformaron "en un movimiento revolucionario de gente pobre que proclamaba la igualdad de los hombres, insistiendo en que todos tenían los mismos títulos para la libertad, heredados de Adán y Eva" ( $\mathrm{COHN}, \mathrm{p}$. 99). El latente y profundo resentimiento de los desposeídos se tradujo en un "igualitarismo militante", según Cohn. "Las últimas cruzadas populares pueden ser consideradas como los primeros ensayos de una suerte de milenarismo que era nuevo en Europa y que pretendía de modo confuso derribar a los poderosos y elevar a los humildes" (CoHN, p. 101). Como sabemos, el sistema feudal permitía la rebelión de los campesinos contra su señor (caso de Alemania) si su gobierno era contrario a la costumbre o tiránico, de manera que las revueltas populares eran conocidas; pero esta hostilidad se fue volviendo hacia los capitalistas de las ciudades que se enriquecían con el comercio y la industria a medida que se desintegraba el sistema feudal y florecía la economía en las ciudades, fenómeno desconocido en Europa.

En este nuevo mundo, en el que el contraste entre la prosperidad y la pobreza e inseguridad era evidente, las protestas de los pobres se 
hicieron frecuentes. Se conservan documentos como proverbios: "El hombre pobre siempre trabaja, se afana, labora y gime, sin reír nunca en su corazón, mientras el rico ríe y canta..." (CoHn, p. 98). También en autosacramentales de la época: "...Cada hombre debería tener propiedad como los demás, pero nosotros nada tenemos...", etc. (CoHn. p. 99). Imperceptiblemente y sin proponérselo, los movimientos milenaristas van perdiendo su carácter religioso primigenio, convirtiéndose en ideologías* seculares prepolíticas y políticas.

Pero no sólo en la Europa premoderna conocemos estos movimientos que buscan la felicidad y salvación presente y futura.

En Melanesia, antropólogos como Linton, Wallace, Worsley y otros encuentran una región privilegiada para el estudio del milenarismo. La creencia nativa en una especie de paraíso, esparcida en aquella zona, el culto a los antepasados y la creencia en su retorno (el mito del eterno retorno) para vivir con sus descendientes en un mundo feliz y perfecto, mitos sobre héroes que habían partido voluntariamente y la espera de su vuelta junto con el advenimiento de tiempos nuevos, libres de enfermedades, privaciones y muerte, hicieron de Melanesia tierra fértil para el milenarismo mesiánico al contacto con la cultura occidental. Wallace llama a este fenómeno social "movimientos de revitalización" que podrían definirse como "un esfuerzo consciente y organizado emprendido por algunos miembros de una sociedad con el fin de crear una cultura más satisfactoria" (WALLACE, pp. 264-281). Uno de los movimientos de mayor relevancia que reúnen estas características surge hacia los años 1860 en el archipiélago de las Islas Fiji en la isla de Viti Levu. Su lider, Ndungumoi, descendiente de una casta sacerdotal, se proclamó enviado celestial dotado de poderes sobrenaturales. Prometía a sus fieles la llegada de los antepasados que aportarían las mercaderías del hombre blanco traídas en grandes navios misteriosos para llenar sus despensas, siendo sus seguidores los únicos que podrían disfrutar de la abundancia (Culto de Cargo). La nueva era que se avecinaba fue una promesa de prosperidad sin trabajo, de juventud eterna en un mundo perfecto. Como en todo movimiento milenarista primitivo, el de Ndungumoi desarrolló una doctrina sincrética de elementos cristianos y aborígenes. La difusión de estas doctrinas tuvo gran alcance. Esta exigía un código moral estricto a sus discípulos y predicaba culpando a los misioneros blancos de ocultar a sus héroes tradicionales en la Biblia, el Libro Santo, bajo los nombres de Jehová y de Jesús. Ndungumoi había venido para descubrir a los impostores. Estas doctrinas y las creencias en el Cargo hicieron que los indígenas abandonaran su trabajo y comercio inmemorial. Si los blancos no trabajaban, ¿por qué habían de hacerlo los nativos? La injusticia llegaría a su fin. Los adeptos a este y a otros movimientos milenaristas semejantes adoptaron actitudes agresivas hacia los misioneros y la adminis-

\footnotetext{
* El concepto de ideología es usado como conjunto de creencias de un grupo con respecto de ciertos aspectos de su cultura.
} 
tración colonial. Llegaría muy pronto el día en que se produciría un trastocamiento de la organización social y política. Temerosas, las autoridades respondieron con la persecución de estos profetas y sus discípulos, tratando así de impedir revueltas. Pero, aunque aparentemente los movimientos eran acallados, volvían a aparecer manteniendo la esencia de su doctrina y el Culto de Cargo, que ahora llegaría en aviones y submarinos traídos por los antepasados en la Segunda Guerra Mundial.

Según Peter Worsley, "sólo una integración más avanzada en la vida occidental permitiría a los aborígenes de Melanesia formular sus reivindicaciones en una forma laica, no ya bajo el disfraz de un movimiento religioso cualquiera" (Worsley, pp. 45-48). El movimiento de Ndungumoi acarreó toda clase de dificultades a las autoridades coloniales hasta que en 1876 fue deportado, muriendo en el destierro. Aunque Worsley considera que el milenarismo aparece, principalmente, en sociedades no literatas, carentes de Estado, sin una autoridad política centralizada, opina que "los movimientos se marchitarán una vez alcanzadas sus metas políticas" (Worsley, p. 225).

Para Ralph Linton, los movimientos como el Culto de Cargo serían "nativistas", poniendo énfasis en la importancia de aspectos culturales indígenas y definiéndolos como todo intento de los miembros de una sociedad con miras a revivificar o perpetuar aspectos de su cultura. El nativismo promete un próximo bienestar social y espiritual en la tierra, dentro de un futuro previsible. Observando el fenómeno social del milenarismo, en este caso podríamos afirmar que es un movimiento esencialmente prepolítico. Wallace, quien hizo un detallado estudio en el distrito de Nadang, Nueva Guinea, habla de una "forma de nacionalismo embrionario", es decir, "una estructura política de desarrollo indígena que expresa la oposición militante a la regla europea y tiene por objeto conjuntar una combinación permanente de grupos políticos hasta ahora autónomos, o asociaciones equivalentes, mediante una autoridad centralizada y un sistema incipiente de clasificación jerárquica" (WALLACE, pp. 58, 264, 281).

- En Africa Negra se conocen movimientos milenaristas desde el siglo XVIII. En el Congo y Africa del Sur la mitología de muchas tribus facilitaba este tipo de reacción político-religiosa al contacto con la catequización portuguesa, que data de 1491 . Un ejemplo reciente del milenarismo mesiánico brota entre los Ba-Kongo, tribu bantú de la región del Congo. La administración blanca quebrantó los antiguos grupos estratificados dominados por jefes aristocráticos de alto rango que además eran jefes religiosos, quitándoles su prestigio sacerdotal y su función de jueces. La religión sufrió una desorganización más rápida que otros sectores sociales ante el proselitismo católico y protestante. En esa atmósfera aparece el gran mesías Ba-Kongo, Simón Kimbangou, quien comienza a predicar hacia 1921, después de su preparación como catequista protestante. Curaciones, milagros, visiones en las que se ve como el emisario de Dios cerca del pueblo negro, hacen de él un 
líder cuyo movimiento se difundió rápidamente y con gran éxito. Sus seguidores sentían orgullo de tener un mesías de su raza. La doctrina de Kimbangou se componia de varios fundamentos: la triste suerte del negro sometido al blanco, exhortación a la resistencia, a la lucha; preceptos morales, la espera del Cristo y la instauración del Reino Celestial en que los blancos serían servidores de los negros. Se estableció en una aldea a la que llamó Nueva Jerusalem y los textos de la Biblia referidos al cautiverio del pueblo judío fueron interpretados como referencias claras a la suerte de los africanos. La reacción de los blancos no se hizo esperar en vista de la importancia que tomó el movimiento. Kimbangou fue encarcelado y luego deportado, así como algunos de sus adeptos. El martirio aumentó el prestigio del movimiento, ya que encarnaba la resistencia en contra de la administración colonial. Después de la muerte del profeta, la secta se reestructuró volviendo a su cauce religioso y "siendo reconocida oficialmente en el país Kongo como Kintwadi, la Iglesia de los Negros" (Doutreloux, p. 76). Como éste, varios movimientos "revitalistas" africanos retienen sólo la responsabilidad de la doctrina y la ejecución del ritual, dejando de ser movimientos para convertirse de hecho en iglesia o, en algunos casos, en partido político.

- Notables ejemplos de milenarismo se dan entre las tribus del oeste norteamericano, atrayendo a importantes contingentes de la población desde fines del siglo XVIII y hasta fines del siglo XX. Básicamente, la doctrina, predicada por jefes visionarios, anunciaba la vuelta a la antigua vida tribal y la alianza con tribus enemigas, logrando así el dominio de los blancos. Su código moral consistía en un ascetismo que "prohibía la embriaguez ritual, la poligamia, los cantos religiosos tradicionales y la magia, que eran importantes elementos de su género de vida anterior". "Incorporaban también a sus prácticas elementos cristianos, convirtiendo las antiguas creencias en un imposible de alcanzar" (MooneY, p. 694). El primer movimiento milenarista conocido entre las tribus norteamericanas apareció en la región de Ohio en 1762, tomando el nombre del ritual religioso principal que el jefe enseñaba a sus fieles, "La Danza del Profeta". Este grupo fue dispersado por los blancos, surgiendo otros dirigidos por nuevos mesías en diferentes regiones, dando lugar a luchas sangrientas entre indios y colonizadores. Desorganizada la vida de los indios Otawa, Creek, etc., por los años 1840 aproximadamente, los movimientos mesiánicos en apariencia desaparecieron. Pero, desde 1870 en adelante, éstos emergen nuevamente con gran vigor. En los territorios de Nevada y California del Norte y luego hasta las Grandes Llanuras, casi en el límite con Canadá, se propagan de manera fulminante, en la medida que el hombre blanco va ganando territorio indio. Todos estos movimientos fueron llamados Ghost Dance Religion (Religión de la Danza de los Espíritus), porque los trances de los fieles tomaban la forma de danzas religiosas. Sólo los antepasados de los que creyeran regresarían a la tierra, y la participación en una danza ritual apresuraría su llegada. 
Según el tipo de contacto entre indios y colonizadores, la doctrina de la Ghost Dance era pacífica o beligerante. Uno de los más importantes profetas de esta doctrina fue Wovoka. Wovoka y sus discípulos afirmaban que sueños y visiones los mantenían en contacto permanente con el más allá y sus antepasados. No formulaba amenazas contra los blancos, afirmando que no eran los indios quienes debían exterminarlos, sino Dios mismo o fuerzas sobrenaturales. De esta manera la doctrina podía ser pacífica, como en el caso de los Paiute (Nevada), que no habían sido expulsados de sus tierras, trabajando dentro de un contexto más o menos semejante al de su vida nativa anterior, contratados como "peones" del colonizador. Pero en cambio los Sioux, privados muy pronto por el blanco del elemento central de su civilización, el búfalo exterminado casi en su totalidad, tomaron una actitud beligerante. Sus líderes ordenaban como un deber el de expulsar y aún el de exterminar al invasor blanco por su propia mano, alcanzando su lucha la violencia más extrema. En su caso, la Ghost Dance resucitaría a los muertos, pero su llegada sería precedida de catástrofes que asolarían al mundo, destruyendo al blanco. Sólo los indios se salvarían. Algunos grupos Sioux pedían que se matara a todos los blancos para recuperar más pronto el paraíso prometido y añorado. El mensaje pacífico no fructificó, terminando su lucha en tragedia. Sitting Bull (Toro Sentado) fue uno de los últimos jefes sioux que participaba de estas creencias y que derrotó al general Custer.

La difusión y permanencia de la Ghost Dance Religion hasta el siglo XX se debe principalmente a la adecuación de elementos religiosos autóctonos y la conservación de éstos, junto a la asimilación de elementos religiosos occidentales.

En Estados Unidos, durante la segunda mitad del siglo XVIII y principios del siglo XIX hubo 36 movimientos milenaristas. En su gran mayoría los in tegrantes eran de origen europeo, ingleses o alemanes. Fueron grupos inconformistas que abandonaron su antigua religión después de la institucionalización de la Reforma al considerar que su causa había sido traicionada. Consecuentemente, estas nuevas comunidades predicaban la primacía de la iluminación interior y de las revelaciones aportadas por el Espiritu Santo. Los emigrantes que llegaron al Nuevo Mundo reaccionaron contra la transformación que se operaba en Europa por la Revolución Industrial: artesanos sin trabajo, desorganización en el campo y la ciudad, etc., pésimas condiciones de vida en las que se veía la llegada del Reino del Anticristo. En Estados Unidos fueron independientes, gozando de una autarquía económico-política en sus inmensos territorios, organizándose en comunidades agrícolas y artesanales autoabastecidas, sin relacionarse con los poderes públicos y la sociedad global. Así, los predicadores proliferaron libremente. Los más famosos fueron los shakers, siendo el comunismo su ley económica fundamental.

Movimientos parecidos a los de los indios del oeste norteamericano existieron también en América del Sur, en especial entre las tribus 
brasileñas. Los movimientos milenaristas primitivos en Brasil se dieron en dos situaciones diferentes: una de contacto de tipo igualitario más antiguo dentro de una aculturación pacífica con el colonizador portugués, y la otra en un contacto de tipo colonial que se desarrolla con la introducción de las plantaciones de caña de azúcar. Ninguna de estas dos situaciones ha desaparecido totalmente en nuestros días.

Los guaranies han sido desde antaño, según los estudios de Egon Schaden, excelentes exponentes del milenarismo mesiánico. La estructura del grupo guaraní estaba basada en la religión y su jefatura descansaba sobre el íntimo contacto con lo sobrenatural. Toda la jerarquía social es fundamentalmente religiosa. Cada jefe de familia conyugal es jefe religioso de aquel grupo; podrá llegar a ser jefe y curandero de la familia extendida si tiene las cualidades religiosas requeridas. "La dirección política del grupo coincide con la dirección carismática del sacerd ote o curandero" (SCHADEN, pp. 113-116). "Para ser cacique hay que saber orar" es una afirmación recogida por Schaden de un jefe guarani. Siendo las creencias religiosas el elemento primordial de la autoridad de la "familia ampliada", en cuanto se las pone en duda se hunde todo el sistema de autoridad. Los movimientos milenaristas en Brasil buscan la "Tierra sin Mal", inspirados en los mitos tribales. El profeta o jefe carismático recibe un día en un sueño la advertencia del próximo fin del mundo; si quiere salvarse de la catástrofe, ha de partir hacia la "Tierra sin Mal". Prepara la partida danzando con su familia y cuando oye el trueno divino que anuncia el desastre final, abandona su aldea y se va al litoral. Acechados por los peligros, finalmente llegan a la orilla del océano, construyendo la "casa de la danza" y reanudando el rito con todos los suyos. Empieza el incendio del mundo seguido del diluvio, pero se sigue danzando... Los movimientos guaraníes siguen el mito paso a paso, pero nunca han llegado hasta el fin. Danzan con toda su fe, pero "sus cuerpos no son lo bastante ligeros para volar a la morada ancestral" (SCHADEN, p. 175), la "Tierra sin Mal".

A fines del siglo XIX, el territorio del alto Rio Negro de la Amazonia se destaca por sus actividades milenaristas, que coinciden con el período de desarrollo de la región amazónica. La importancia cada vez may or del caucho atrajo a toda clase de aventureros que, rechazando a las tribus indígenas, les quitaban sus tierras. Entre varios otros mesías se destaca el Cristo Alejandro, mestizo que había recibido formación católica. Este asume como líder predicando, enseñando y bautizando. Su doctrina sincrética exigía una obediencia ciega a sus prosélitos quienes, a la menor falta, eran castigados. Predicó abiertamente la rebelión contra el gobierno brasileño, que se había apoderado de las tierras de los indios, y anunció cambios inminentes en que los blancos serían sometidos a la esclavitud y los indios reanudarían su vida antigua. Fundó una Ciudad Santa y fueron tantos sus seguidores y la violencia de sus amenazas, que el gobierno de la provincia envió tropas contra la Ciudad Santa ante la "conspiración contra las gentes civili- 
zadas" (Archivo do Amazonas, No 7, p. 88), desbaratando el movimiento.

Observamos que el nativismo y el revivitalismo u otros tipos de movimientos de revitalización suelen pasar por algunas etapas características: situación estable; creciente tensión; organización; adaptación (resistencia de intereses creados que deben ser derrotados por conversión o combate); transformación cultural; rutinización y situación estable, pudiendo reanudarse un nuevo ciclo (WALLACE, pp. 271-280).

Chile tuvo un notable caso de milenarismo que incidió en el pensamiento teológico europeo.

El sacerdote jesuita chileno Padre Manuel Lacunza, establecido en Italia después de la expulsión de su Orden de los dominios españoles, escribió entre otros el libro La Venida del Mesias en Gloria y Majestad, en el que anuncia "la segunda venida de Cristo de un modo infinitamente diverso". Esta obra fue incluida entre los libros prohibidos del Indice Romano por su evidente tendencia milenarista. Sin embargo, se dice de Lacunza que "es una de las glorias de la Teología en el presente siglo i una de las glorias de su patria..." (José Domingo Cortés, pp. 262-263), y Encina escribe: "Este libro chileno ha alcanzado la más alta cumbre como esfuerzo de in teligencia...". "Es el que ha alcanzado mayor celebridad y el único que ha repercutido en el pensamiento universal hasta el momento en que escribimos" (ENCINA, pp. 626627).

- La Europa moderna se ve estremecida por movimientos sociales cuyas consecuencias perduran e influyen en la política mundial hasta el presente. Al interior de éstos, coexisten elementos claros del milenarismo junto a la extrema secularización de sus ideologías.

En una breve descripción diacrónica, trataremos de resumir tres de los más recientes e influyentes movimientos.

A mediados del siglo XIX el marxismo como cuerpo de doctrinas revolucionarias de Marx y Engels tiene la misión de promover la clase trabajadora, aboliendo el capitalismo y privilegios de clase. Su meta es la de crear una sociedad sin clases, sin Estado, pasando por la dictadura del proletariado. El conflicto, el enfrentamiento entre clases, es la base dialéctica de los desarrollos políticos propios del marxismo. Una clase es el proletariado, poseedor sólo de la venta de su trabajo, y cuya renta se origina en el pago de éste. Dentro de esta categoría Marx incluye la "intelligentsia", las profesiones liberales, los artesanos, oficios y obreros no especializados, así como la clase residual precapitalista como campesinos en vías de proletarización.

La otra clase, la burguesía, compuesta por terratenientes cuya renta se origina en la tierra, los industriales que poseen los medios de producción y de los accionistas que poseen el capital que permite la apropiación de los medios de producción. Para Cohn es innegable la presencia de la idea milenarista de "las tres edades", los tres reinos, expuestas en la teoría de la evolución histórica por filósofos idealistas alemanes como Lessing, Schelling y, en cierta medida, Hegel. Auguste 
Comte describe la historia en fases teológica, metafísica y científica. "También en la dialéctica marxista de las tres etapas del comunismo primitivo, la sociedad de clases y el comunismo final que ha de ser el reino de la libertad y en el que desaparecerá el Estado" (CoHn, p. 108).

Las doctrinas escatológicas y milenaristas son relevantes en el comunismo marxista, señalando el papel redentor del proletariado que, en una sociedad sin clases, logrará una utópica época de paz y prosperidad, la Edad de Oro. "Marx ha enriquecido este mito venerable con toda una ideología mesiánica judeocristiana: por una parte, el papel profético y la función sotereológica que concede al proletariado; por otra, la lucha final entre el Bien y el Mal, que puede fácilmente ponerse en relación con el conflicto apocalíptico entre Cristo y el Anticristo, seguida de la definitiva victoria del primero"(EL1ADE, p. 191). Marx también asume en su doctrina la esperanza escatológica judeocristiana de un fin absoluto de la Historia, separándose así de otros filósofos historicistas, para los que las tensiones, "siendo consustancias al hombre, no podrán ser eliminadas en su totalidad" (El1A DE, p. 191). El milenarismo se mueve dentro de una concepción histórica y una concepción ahistórica del tiempo.

El fascismo tiene su origen en los "fascii", nombre de las asociaciones de obreros y campesinos sicilianos, unidos para luchar contra la gran propiedad rural y los exorbitantes impuestos. Una vez que se organizan, piden una reforma agraria con sindicatos agricolas e industriales, ayudados por el Estado. El movimiento de los fascii fue complejo, siendo sociedades de asistencia y ayuda mutua, así como revolucionarios, siempre listos para la insurrección. El fascismo se identifica con el movimiento ideológico, político y social que sigue las doctrinas de Mussolini en Italia (1919), estrechamente emparentado con el nacionalsocialismo alemán. Se presenta como una nueva reivindicación de los más necesitados, prometiendo viviendas, alimentos, trabajo, etc., y un sistema político bajo un vigoroso Estado corporativo (1934). Fue un movimiento de masas al que recurrió una sociedad anómica en período crítico, buscando estabilidad e identidad, así como satisfacción de necesidades. Su líder, el Duce, adopta el emblema de un haz de varas con un hacha atada, símbolo de la autoridad de los magistrados de la antigua Roma, los ligures.

Mussolini se adueña del poder en la llamada "marcha sobre Roma", creando un régimen dictatorial de partido único bajo la autoridad absoluta del Duce. Este modelo político se asemeja al culto romano divino, sentimiento capaz de darle la cohesión necesaria. Mussolini exalta el concepto de conquista por la fuerza, la lucha. Rechaza el pacifismo, tratando de revivir el pasado glorioso del Antiguo Imperio Romano, prometiendo hacer de Italia una gran potencia. Toda sociedad totalitaria vive dentro de una cultura común, mito que necesita de un símbolo personal. En este caso es el Duce el que le da el sentimiento de cohesión necesario. En el fascismo se encuentren elementos milenaristas que no se ocultan bajo una aparen- 
te religiosidad, sino que emerge como movimiento secular basado en una ideologia política.

En Alemania, el Tercer Reich de Hitler, con su símbolo de la cruz swástica, es otro ejemplo de milenarismo moderno, basado en la supremacía del mito "de la raza aria", una raza superior. Dice Mircea Eliade: "La pasión por el origen noble explica asimismo el mito racista de los "arios'...". "Los contextos sociopolíticos de este mito son demasiado conocidos para insistir en ello. Lo que nos interesa aquí es que el 'ario' representaba a la vez al antepasado 'primordial' y al 'héroe' noble revestido de todas las virtudes..." (EL1ADE, pp. 190-191). "El ario era el modelo ejemplar a imitar para recuperar (...) la moral heroica de los comienzos gloriosos y creadores" (ELIADE, p. 191). El "Nuevo Orden" del Führer combina una serie de elementos como la ambigüedad del nacionalsocialismo, que aglutina a los más diversos grupos sociales e ideológicos y lo usa como arma contra el bolcheviquismo, antisemitismo, como revolución de los estratos sociales afectados por la inflación, la crisis económica, los desarraigados de la guerra, como movimiento militante de un pueblo arrogante que ha sido humillado por Europa, y que desea reivindicarse conquistando la supremacía sobre el mundo. Adolf Hitler como líder indiscutible es aceptado y admirado "como un mesías, como un salvador" (Larousse Mensuel Ilustré, París, Tomo IX, 1929-1934, p. 568). La obsesión de Hitler es la de hacer revivir "las verdaderas tradiciones germánicas". Para poner en marcha su movimiento de revitalización, recurre al "mito de origen", proponiendo el matrimonio como "una institución destinada a crear seres a imagen del Señor y no a monstruos mitad hombre mitad mono" (Hitler, p. 165). Manipula la religión como medio para alcanzar el poder diciendo: "Para el político, la apreciación del valor de una religión debe regirse menos por las diferencias innatas en ella, que por la bondad cualitativa de un sustituto doctrinal visiblemente mejor" (Hıtler, p. 122). "También en esto la Iglesia Católica debe servirnos de ejemplo, ya que, a pesar de que su cuerpo doctrinal está en colisión en muchos puntos", según Hitler referidos a confrontaciones con la ciencia. "...jamás se resigna a sacrificar un ápice de su doctrina" (Hitler, p. 192).

$\mathrm{Su}$ errónea concepción de la fe, junto a su ignorancia en materia religiosa, son en este líder herramientas útiles para revivir las creencias milenaristas del pueblo alemán. Durante el reinado de Federico Barbarroja (1190) en la Tercera Cruzada, aparecen exaltaciones milenaristas y mitos escatológicos que hablaban de un futuro Federico quien, como Emperador de los Ultimos Días "(...) sería un salvador escatológico que, liberando el Santo Sepulcro, prepararía el camino para la segunda venida y el Milenio"' (CoHn, p. 110). Años después, Federico II es mirado como ese salvador. Los pobres serían beneficiados al fin con las riquezas de los ricos y dejarían de ser oprimidos. Estas ideas estimulan un cambio social radical que pudo llegar a ser un movimiento revolucionario. Pero Federico [I fallece y así el pueblo comienza a 
esperar su resurrección y "antes que pasase mucho tiempo se reunirían bajo la égida del Emperador Federico. (...) No sólo al que recuerda el Emperador de los Ultimos Días, sino también al mesías de las apocalípticas judeocristianas" (CoHN, p. 119).

"Los partidos políticos se prestan a compromisos, las concepciones ideológicas jamás. Los partidos políticos cuentan con competidores, las concepciones ideológicas suponen y proclaman su infalibilidad" (Hitler, p. 190).

El Tercer Reich aparece como el "Nuevo Orden que debería durar mil años". Esta doctrina prende como llama en la paja, habiendo estado profundamente enraizada en la cultura mitológica germana durante siglos, lo que permite a Hitler el liderazgo absoluto. "El pensamiento mítico puede sobrepasar y rechazar algunas de sus expresiones anteriores (caídas en desuso por la Historia), adaptarse a las nuevas condiciones-sociales y a las nuevas modas culturales, pero no logra extirparse" (ELIADE, p. 184).

Esta cita ayuda a explicar la relación entre el líder carismático que se convierte en símbolo de un movimiento milenarista de esta índole. La encarnación del mito en la persona del salvador y la perfecta congruencia de su mensaje con las creencias ancestrales, las necesidades del presente junto a las expectativas para el futuro, permiten una entrega incondicional del pueblo a su rendendor. La Tierra sin Mal, un mundo libre de privaciones, compensará los sacrificios exigidos. Aunque los rituales de rebelión para recorrer el camino a ese "Nuevo Orden" impliquen sufrimientos, renuncia hasta el martirio y el genocidio, el magnetismo que irradia su profeta y su mensaje de superioridad en la perfección y la felicidad terrenal futura, lo atrae irremisiblemente. Así, muchos han sucumbido a la tentación de la destrucción como aquellos niños que en épocas pasadas (Cruzadas de los Niños) fueron arrastrados a su muerte envueltos en la música del flautista de Hamelin.

\section{CONCEPTOS}

Un movimiento social podría ser definido como el intento colectivo para lograr cambiar determinadas instituciones sociales o crear un orden totalmente nuevo. Su acción se basa en el sentimiento de pertenencia y solidaridad con los demás miembros del grupo y la voluntad colectiva empeñada en la consecución de un fin común. La propiedad, la distribución de bienes y la distribución del poder están estrechamente ligadas a los movimientos sociales.

Los ejemplos de milenarismo escogidos pueden ser separados en categorías. Aquellos que motivan revueltas y disturbios entre los estratos sociales bajos que pretenden mejorar su condición social: en la Europa premoderna surgen movimientos de tendencia radicalizante, con carácter religioso o semirreligioso y miras a una transformación 
económica y política, pero sin atacar los cimientos del orden social; movimientos similares emergen al contacto de sociedades atrasadas en su incorporación al mundo moderno, así como también el proceso de interpenetración y aculturación entre sociedades primitivas y modernas han estimulado el milenarismo. Es común a estos movimientos milenaristas el fracaso de su pretendido cambio social, ya que no suelen adoptar ideologías, tácticas ni organización para lograr sus propósitos, siendo finalmente aplastados o absorbidos por la sociedad mayor. Y por último movimientos nacionalistas que se organizan para aniquilar la institucionalidad vigente, promoviendo un nuevo orden, como ha sucedido en Europa contemporánea.

Aun siendo cada movimiento milenarista original y singular, tienen características doctrinales comunes, como lo afirma Cohn. Estos movimientos conciben la salvación como un hecho: colectivo en el sentido de que debe ser disfrutado por la colectividad; terrenal, ya que debe realizarse en la tierra y no fuera de este mundo; inminente, puesto que transformará la vida en la tierra, no como una mejoría, sino alcanzando la perfección; milagroso, ya que debe realizarse con ayuda sobrenatural o a través de un mediador entre lo humano y lo divino, que exige de sus prosélitos una fe y una lealtad incondicionales.

Asimismo, podríamos clasificar en dos grandes grupos los movimientos antes descritos: movimientos de clase y movimientos étnicos. Como ejemplo de los primeros tenemos los de campesinos frente a terratenientes, los de trabajadores contra patrones, etc. En suma, los de los pobres contra los ricos. Las clases que forman movimientos milenaristas se sienten económicamente explotadas y políticamente oprimidas. Al no concretarse sus anhelos reivindicativos, y sin poseer una ideología elaborada, éstos se vuelven erráticos, radicales y, en oportunidades, revolucionarios. El hecho de que un movimiento sea apoyado por una clase determinada no significa que todos los miembros de esa clase pertenezcan a ella. Ciertos movimientos se nutren de los miembros desarraigados o marginados (por ejemplo, la mayoría de los nazis, Hitler incluido, eran "déclassés", procedentes de la clase media baja). Los iniciadores y profetas del sistema de creencias, de la doctrina de un movimiento de clase, son frecuentemente alienados de otra. Marx incluye como miembros del proletariado a la "intelligentsia", que en algunos casos suministra líderes carismáticos a los movimientos revolucionarios.

Dentro de la segunda clasificación, movimientos étnicos, se agrupan diversos fenómenos sociales que pueden ser diferentes entre sí, con un patrón básico común: movimientos de minorías nacionales al interés de antiguos imperios de Europa; movimientos de unificación nacional (Italia y Alemania); de independencia de los nativos de colonias europeas de ultramar; movimientos que tienden a liberarse del blanco, así como de enriquecerse con su civilización; como el de los "musulmanes" negros en EE.UU.; movimientos de minorías nacionales en países en vías de desarrollo, etc. 
Existen diversas apreciaciones sobre las causas que producirían los movimientos milenaristas. El profesor Augusto Merino (ver Bibliografía) es de opinión de que una de las razones sería la reacción frente al empeoramiento de las condiciones de vida y perspectivas aun más sombrías para el futuro. Es una creencia propia de los grupos que experimentan sufrimientos colectivos intolerables. Como lo vimos con anterioridad, Worsley los considera como movimientos prepolíticos y su comportamiento emocional y agresivo tiene relación con el carácter revolucionario del movimiento que lucha por la destrucción de las instituciones existentes y el establecimiento de un orden nuevo. La situación de ciertas sociedades tecnológicamente atrasadas, con una superpoblación y pobreza desesperada, envueltas en la transición al mundo moderno, es también una posible causa de brotes milenaristas. En sociedades con tecnologías avanzadas, elementos políticamente marginados se organizan en movimientos milenaristas como un medio para alcanzar el poder político. La aparición de estos movimientos se ha conocido después de desastres naturales, crisis económicas, guerras, privaciones, frustraciones, ausencia de canales de expresión política del pueblo, etc., siendo considerados como fenómenos postpolíticos.

Pero otras razones que aparentemente se contradicen con lo anterior son dignas de mención. Hay estallidos milenaristas que se han producido a raíz de una mejoría limitada de las condiciones de vida, que levantó nuevas expectativas e ilusiones y no llegaron a concretarse. En naciones africanas han reaparecido varios movimientos milenaristas después de su independencia, ante la honda insatisfacción referida a las esperanzas frustradas por la dura realidad. El cambio social introducido por una cultura ajena, que ante los ojos del aborigen puede ser prestigiosa y su confrontación con el sistema valórico tradicional, provoca diferentes grados de desintegración normativa, ya que las influencias exógenas quiebran el sistema tradicional sin que alcance a ser sustituido por otro. Así, el grupo social cae en un estado de alienación $\mathrm{y}$ anomia que propende al brote del milenarismo como una solución a la búsqueda de valores e identidad cultural.

Cohn subraya las funciones negativas del milenarismo y lo considera como una peligrosa locura colectiva, "ya que la consideración megalomaníaca de uno nismo como ser perfecto y la atribución de poderes casi demoníacos al adversario" hacen según él "que el milenarismo sea una ideología perturbadora y hasta aniquiladora para el movimiento en sí y la realidad en general" (СонN, p. 286).

Worsley, a su vez, destaca las funciones positivas del milenarismo y afirma que los elementos predominantes en él son la esperanza, la solidaridad, la rehabilitación interior de los individuos y la capacidad del movimiento para activar y unificar grupos, rescatándolos de la segregación e inercia, logrando ser en la historia contemporánea el precursor del "despertar político y de la organización política" (p. 24).

Wallace considera que el milenarismo tiende un puente entre el pasado y el futuro, explicando las interconexiones y semejanzas funda- 
mentales entre los movimientos religiosos y seculares que constituyen una característica importante para comprender el alcance que ha tenido el milenarismo a lo largo de la historia y que subyace en muchos movimientos políticos.

Bastide afirma que el milenarismo ha desempeñado un importante papel en todos los movimientos de liberación nacional y social de la Europa premoderna y moderna. Asimismo, ha precedido e informado a muchos movimientos nacionales y sociales incipientes de los países en desarrollo.

\section{REFLEXIONES}

En este artículo no se ha pretendido hacer un estudio exhaustivo del milenarismo, que de por sí es un tema difícil de agotar, sino que utilizar, por medio de los ejemplos e investigaciones, algunos de los conceptos ya recogidos, aplicándolos al presente.

- Como decíamos al comenzar, los medios de comunicación masiva que llegan hasta los más recónditos lugares anunciando cambios fabulosos a corto plazo, pregonando un paraiso terrenal "ad portas", incentivando el apetito por un consumismo innecesario, introduciendo expectativas fuera de nuestro alcance, provocan una angustiante frustación así como una peligrosa esperanza. La informática ya no es sólo una consecuencia del genio del hombre sino que, superándolo, se ha exagerado su poder hasta elevarla al rango de divinidad mítica como neosalvadora que hoy es amenazada por el anticristo del virus de la antiinformática, haciéndonos temer una debacle universal fuera del control humano. Nuestra cultura es embestida una vez más por el flujo de tecnologías ajenas, demostrándonos la propia obsolescencia.

- No es posible ni deseable que América Latina quede marginada de acceder a ese "mundo feliz"; pero la reinterpretación de la modernización y del progreso asi como las formas de alcanzar ese "futuro perfecto" son un derecho que nos pertenece y que debe ser realizable de acuerdo a nuestro propio ritmo, a nuestra particular apreciación del tiempo, aunque no coincida con la llegada del año 2000. La proximidad del Tercer Milenio incita, consciente o inconscientemente, a recurrir al mito. La necesidad del hombre primitivo así como la del civilizado de buscar la bondad y la justicia ha sido una constante comprobada en múltiples investigaciones de cientistas sociales, en especial de antropólogos, que insisten en la premisa de que antes de que se hiciera presente el hombre blanco existían creencias nativas que encerraban la promesa de una tierra feliz y la salvación eterna para los justos. Al contacto con la doctrina judeocristiana, se gestan doctrinas sincréticas con el sello particular de cada cultura.

- Muchos movimientos sociales no son milenaristas, pero sorprende la cantidad y diversidad de éstos que, reuniendo los rasgos doctrinales esenciales del milenarismo, permanecen a través de los siglos. Que 
en los movimientos milenaristas de la sociedad moderna prevalezca su carácter religioso, es cuestión de la opción de aquellos que ostentan el poder político y económico, ya que los fenómenos religiosos y seculares se excluyen mutuamente. Son de importancia el grado de diferenciación de la sociedad, las características de las esferas políticas, la legitimidad del poder y las posibilidades de grupos minoritarios de alcanzar algunas de sus finalidades mediante la acción política institucionalizada.

- El modo peculiar de resolver los conflictos es derivado de los principios estructurales de asociación humana vigente en una sociedad. El escisionismo de tipo cismático que aparece manifestándose en la estructuración de subgrupos de sociedades amplias puede deberse a la falta de tolerancia, a la rigidez o a la inexistencia de formas de expresión institucionalizadas que ayuden a resolver los conflictos de manera periódica o permanente, evitando así los estallidos esporádicos o sistemáticos de movimientos violentos y/o revolucionarios.

- Los planteamientos etnográficos de Henry Morgan en su obra League of the Iroquois en 1851 y más tarde de Mooney sobre la Ghost Dance en 1896, entre los indios de las llanuras, interesan a nuevas generaciones de antropólogos que investigan en otros lugares manifestaciones comparables a las descritas por Morgan y Mooney.

-El milenarismo aflora como un movimiento complejo, cuyas causas y efectos son diferentes según su procedencia y motivación. El nativismo aparece como una forma de depurar la sociedad de extraños indeseables y de elementos culturales cuyo origen es foráneo. El revivalismo procura el regreso a una época de felicidad pasada, a la restauración de la tan anhelada edad de oro y a la revivificación de una sociedad plena de virtud. Estos movimientos de revitalización como parte del milenarismo aluden a taxonomías antropológicas aplicables a los fenómenos de las sociedades complejas contemporáneas, sometidas a las tensiones y presiones del rápido cambio cultural y social, y pueden permitir sistemas clasificatorios útiles para acercarse a la comprensión de estos movimientos que aparecen en Latinoamérica y que nos atañen con prioridad.

- La proliferación de grupos minoritarios que aparentemente reúnen los requisitos inherentes a los movimientos milenaristas, afiliados supuestamente en algunos casos, y explícitamente en otros, a ideologías políticas que se expresan mediante la violencia en Colombia, Brasil, Perú, Nicaragua, Paraguay. Chile, etc., es razón suficiente para su continuo análisis científico.

- Finalmente, agregaríamos que la preocupación de la Antropología Social por la descripción de los hechos etnográficos, por el método inductivo y la formulación de hipótesis sobre la conducta humana, plantea un desafío a la Antropología Política frente a la problemática actual de nuestro continente. 


\section{Bibliografía}

Almond, Gabriel. La politica de las áreas en desarrollo, Princeton University Press, 1960.

Bastide, Roger. El prójimo y el extraño, Buenos Aires, Amorrortu editores, 1970.

Cohn, Norman. En pos del milenio, Madrid, Alianza Editorial S.A., 2a Edición, $1981-1983$.

Cortés, Domingo. Diccionario bibliográfico americano, París, 1875.

Coser, Lewis. Las funciones del conflicto social, Buenos Aires, F.C.E., 1961.

Radcliffe-Brown, A.R. Estructura $v$ función en la sociedad primitiva, Barcelona, Editorial Península, 1972.

Dahrendorf, Ralf. Las clases sociales y su conflicto en la sociedad industrial, Madrid, Editorial Rialp S.A., 2a Edición, 1970.

Doutreloux, Albert. Prophétisme et leadership dans la société congolaise, Bélgica, Lovaina, 1961.

Easton, David. El sistema politico, New York, Konpf, 1953.

Encina, Francisco A. Historia de Chile, Tomo III, Santiago, Ed. Nascimento, 1951.

Eliade, Mircea. Mito y realidad, Barcelona, Editorial Labor, 6a Edición, 1985.

Freund, Julien. Sociologie du conflict, París, Editorial P.V.F., la. Edición, 1983.

Hitler, Adolf Mi lucha, Santiago, Editorial Cultura, Chile.

Huxley, Aldous. Un mundo feliz, Buenos Aires, Plaza y Janés S.A., 9a Edición, 1980.

Lawrence, Peter. Road Belong Cargo, Londres, Manchester University Press, 1964.

Linton, Ralph. Nativistic movements, American Anthropologist, vol. $45, \mathrm{~N}^{\circ} 2$, abril-junio 1943 .

Lipset, Seymour M. Politica y ciencias sociales, Madrid, Guardiana de Publicaciones S.A., 1971.

Llobera, José y otros. La antropologia como ciencia. Barcelona, Ed. Anagrama, 1975 .

Maquet, Jacques. El poder negro en Africa, Madrid, Editorial Guadarrama S.A., 1971 .

Marx, Karl. Manuscritos de 1884, Buenos Aires, Ediciones Estudio, 1972.

Merino, Augusto. El milenarismo visto desde la politologia, Santiago, Instituto de Ciencia Politica, Universidad de Chile, 1986-1987 (edición mimeografiada).

Metraux, Alfred. Les messies de l'A mérique du Sud, París, Archives de Sociologie des Religions, $\mathrm{N}^{\circ} 4$, pp. 53-60, 1957.

Mooney, James. The Ghost Dance Religion, Chicago, University Press, 1965.

Salvemini, Gaetano. Bajo el hacha del fascismo, Londres, Gollanz Editores, 1936.

Schaden, Egon. Aspectos fundamentales de la cultura guarani, Sao Paulo, 1954.

Schollen, Gershom C. Major Trends in Jewish Mysticism, 3a Edición, New York, Shoken Ed., 1954.

Sciacca, Michel. Historia de la filosofia, Barcelona, Ed. Luis Miracle S.A., 1966.

Wallace, Anthony. Revitalization Movements, American Anthropologist, New Series (Washington), $\mathrm{N}^{\circ} 58$, pp. 264-281, 1956.

Worsley, Peter. The Trumpet Shall sound, a study of "Cargo" cults in Melanesia, London, Mc Gilbon and Kee, 1957. 